\title{
APAKAH KARAKTERISTIK PEMERINTAH DAERAH BERPENGARUH PADA PENGUNGKAPAN LAPORAN KEUANGAN PEMERINTAH DAERAH? RISET PADA KABUPATEN DI JAWA TENGAH
}

\author{
Dekeng Setyo Budiarto \\ Luki Indarti \\ Universitas PGRI Yogyakarta \\ dekengsb@upy.ac.id
}

\begin{abstract}
Disclosure of information in financial statements is part of Local Government Financial Report (LGFR) accountability and transparency to the public. This study aims to determine the influence of local government characteristics, total population, audit findings, and audit opinion on their financial statement disclosures. The population in this study was a local government of regency/city in central Java province in 2015-2017. The sample in the study was selected by saturation sampling, and the data obtained were 102 financial reports of local government. The analysis technique used in this research was multiple linear regression analysis. Results of the study proved that government's official age and total population variable have a significant effect on the disclosure of local government financial report, while the size of local government, audit opinion, and audit findings variable has no significant impact on the disclosure of LGFR.
\end{abstract}

Keyword : government characteristics, audit findings, audit opinion and financial statement disclosures

\begin{abstract}
ABSTRAK: Keterbukaan informasi dalam laporan keuangan adalah bagian dari pertanggungjawaban dan transparansi Laporan Keuangan Pemerintah Daerah kepada publik. Penelitian ini bertujuan untuk mengetahui pengaruh karakteristik pemerintah daerah, total populasi, temuan audit, dan opini audit terhadap pengungkapan laporan keuangannya. Populasi dalam penelitian ini adalah pemerintah daerah kabupaten / kota di provinsi Jawa Tengah pada tahun 2015-2017. Sampel dalam penelitian ini dipilih dengan sampling jenuh, dan data yang diperoleh adalah 102 laporan keuangan pemerintah daerah. Teknik analisis yang digunakan dalam penelitian ini adalah analisis regresi linier berganda. Hasil penelitian membuktikan bahwa usia resmi pemerintah dan variabel total populasi memiliki pengaruh signifikan terhadap pengungkapan laporan keuangan pemerintah daerah, sedangkan ukuran pemerintah daerah, opini audit, dan variabel temuan audit tidak memiliki dampak signifikan terhadap pengungkapan LGFR.
\end{abstract}

Kata kunci: karakteristik pemerintah, temuan audit, opini audit, dan laporan keuangan pengungkapan

\section{Pendahuluan}

Tahun 2018 Badan Pemeriksa Keuangan (BPK) perwakilan Jawa Tengah menyatakan berdasarkan temuan, masih banyak pemerintah daerah yang melanggar peraturan. Temuan BPK menjelaskan bahwa pelanggaran masih terjadi terutama pada pengendalian internal dan kepatuhan pemda pada peraturan. Permasalahan yang diungkapkan BPK di antaranya mengenai akuntabilitas dana bantuan operasional sekolah, aset daerah, inventory, pengadaan barang \& jasa,belanja bantuan sosial, hibah, dana operasional, dan tunjangan komunikasi intensif, serta tunjangan reses pimpinan DPRD (Semarang.bpk.go.id). Permasalahan yang terjadi harus diatasi demi mewujudkan tata kelola yang baik (good governance). Salah satu usaha yang dilakukan pemerintah yaitu dengan meningkatkan akuntabilitas pengelolaan keuangan negara terutama kepatuhan hukum, kelemahan sistem, serta 
meningkatkan kualitas SDM (Suhardjanto dan Yulianingtyas, 2011).

Meningkatkan akuntabilitas dan transparansi pengelolaan keuangan pemerintah daerah agar tercapai good governance memerlukan perubahan dalam bidang standar akuntansi pemerintahan. Perubahan yang dilakukan terkait dengan penyajian laporan keuangan harus mengacu pada SAP untuk meningkatkan akuntabilitas laporan keuangan. Perubahan yang dilakukan akan meningkatkan kredibilitas laporan keuangan sehingga dapat mendorong transparansi dan akuntabilitas untuk mencapai good governance (Niu et al., 2014).

Standar akuntansi pemerintahan (SAP) mengatur dua pengungkapan laporan keuangan pemerintah daerah yaitu mandatory disclousure dan voluntary disclosure. Mandatory disclosure berarti bahwa pemerintah wajib mengungkapkan informasi sesuai dengan hukum yang berlaku. Voluntary disclosure merupakan pengungkapan informasi selain pengungkapan wajib yang merupakan informasi tambahan bagi stakeholder (Setyaningrum dan Syafitri, 2012). Pemerintah daerah wajib menyajikan laporan keuangan sebagai akuntabilitas atas penggunaan sumberdaya. Laporan keuangan yang berisi seluruh transaksi harus diungkapkan secara relevan oleh masing-masing pemerintah daerah (Lesmana, 2010)

Pengungkapan atau transparansi laporan keuangan pemerintah daerah (LKPD) dipengaruhi oleh banyak faktor yaitu: karakteristik daerah yang diproksikan dari ukuran pemerintahan dan umur pemerintah, jumlah penduduk, temuan audit, dan opini audit (Alhajjriana et al., 2017). Selain itu, Marfiana dan Kurniasih (2013) mengungkapkan bahwa faktor yang mempengaruhi transparansi yaitu karakteristik pemda dan hasil audit BPK.

Beberapa peneliti telah meneliti mengenai pengaruh karakteristik pemda, banyaknya penduduk, temuan audit dan opini audit terhadap pengungkapan laporan keuangan pemerintah daerah (LKPD). Beberapa peneliti menemukan bahwa variabel karakteristik pemda, jumlah penduduk, temuan audit dan opini tidak berpengaruh terhadap pengungkapan laporan keuangan pemerintah daerah (Marfiana dan Kurniasih, 2013; Naopal et al., 2017; Masdiantini dan Erawati, 2016). Penelitian lain menyatakan bahwa variabel karakteristik pemerintah daerah, jumlah penduduk, temuan audit dan opini audit memiliki pengaruh (Mustikarini dan Fitriasari, 2012; Hilmi dan Martani, 2012).

Berdasarkan beberapa hasil penelitian terdahulu yang tidak konsisten peneliti akan menguji kembali faktor-faktor yang mempengaruhi pengungkapan laporan keuangan pemerintah daerah. Penelitian mengenai pengungkapan laporan keuangan telah banyak dilakukan tetapi pada perusahaan swasta. Berdasarkan penelitian Pradipta dan Azizah (2016), Dewi dan Yasa (2017), Nurkhin (2009), Sulisnaningrum dan Prabowo (2017), Wahyuningsih et al. (2016) faktor yang mempengaruhi pengungkapan pada perusahaan swasta yaitu ukuran perusahaan, umur perusahaan, leverage, profitabilitas, likuiditas, porsi saham, status korporasi, tipe industri, dan corporate governance. Berdasarkan beberapa penelitian terdahulu penelitian ini akan menguji pengungkapan Laporan Keuangan Pemerintah Daerah di Jawa Tengah yang belum banyak dilakukan.

\section{Landasan Teori \\ Laporan keuangan pemerintah daerah}

Menurut UU No 71 tahun 2010, Laporan keuangan pemda merupakan laporan keuangan yang menyajikan kegiatan oprasional pemerintahan serta posisi kekayaan dan kewajiban yang dapat dipenuhi oleh pemerintahan. Laporan keuangan pemerintah daerah terdiri dari Laporan Realisasi Anggaran (LRA), Laporan Perubahan SAL, Neraca, Laporan Operasional (LO), Laporan Perubahan Ekuitas (LPE), dan Catatan atas Laporan Keuangan (CaLK). Berdasarkan UU 71 tahun 2010 tujuan penyajian laporan keuangan pemerintah adalah menyajikan informasi mengenai posisi keuangan. Selain itu laporan keuangan juga berisi laporan 
realisasi anggaran, laporan arus kas pemerintah daerah. Laporan keuangan yang disajikan pemeritah daerah akan bermanfaat bagi stakeholder untuk pengambilan keputusan (Pradono, 2015). Laporan keuangan pemerintahan dapat diandalkan oleh pengguna informasi jika laporan disajikan secara akuntabel. Akuntabilitas laporan keuangan dapat dicapai jika pemerintah menerapkan sistem akuntasi berbasis akrual (Bowrey, 2007).

\section{Pengungkapan LKPD dalam CaLK}

Catatan atas Laporan Keuangan merupakan bagian dari laporan keuangan yang dapat digunakan stakeholder secara lebih luas (Naopal et al., 2017). UU No 71 Tahun 2010 menjelaskan bahwa Catatan atas Laporan Keuangan menyajikan entitas, kebijakan fiskal, target dan kendala serta kebijakan akuntansi. Selain itu CaLK berisi informasi tentang pernyataan standar akuntansi yang belum digunakan oleh pemerintah daerah.

\section{Karakteristik Pemerintah Daerah}

Karakteristik pemerintah daerah pada penelitian ini diproksikan dalam dua variabel yaitu ukuran pemerintah daerah dan umur pemerintah daerah (Marfiana dan Kurniasih, 2013)

\section{Ukuran pemerintahan}

Aset daerah merupakan bagian atau komponen yang sangat penting dalam penyajian neraca. Aset daerah terdiri dari aset tetap dan aset lancar serta inventory. Oleh karena itu tata kelola aset daerah yang baik akan mendorong terciptanya laporan keuangan yang baik (Yusuf, 2010; Simamora dan Halim, 2013).

Ukuran suatu entitas atau pemerintah daerah menunjukkan besar atau kecilnya pemerintah daerah. Salah satu ukuran yang digunakan untuk menilai besar kecilnya pemerintah daerah adalah dengan total aset. Ukuran pemerintah daerah akan berbanding lurus dengan jumlah aset yang dimiliki (Khasanah dan Rahardjo, 2014; Aziz 2016).

\section{Umur pemerintah}

Umur pemerintah daerah atau organisasi dapat diukur dengan lamanya organisasi berdiri. Umur administratif suatu organisasi terutama pemerintah daerah diukur dengan umur berdirinya yang didasarkan pada peraturan. Suatu organisasi yang memiliki umur administratif yang lebih lama akan memiliki pengalaman dalam menyusun laporan keuangan. Umur administratif yang lebih lama cenderung akan menggunakan pengalaman untuk mengungkapkan informasi yang wajar sesuai standar akuntansi yang berlaku (Setyaningrum dan Syafitri, 2012).

\section{Jumlah Penduduk}

Penduduk merupakan semua warga yang bertempat tinggal di wilayah Republik Indonesia selama lebih dari enam bulan. Selain itu penduduk merupakan warga negara yang bertujuan untuk menetap meskipun kurang dari enam bulan (www.jateng.bps.go.id). Jumlah penduduk diperoleh melalui sensus penduduk dengan periode 10 tahun. Sensus penduduk akan mencatat seluruh warga negara yang berdomisili di wilayah Indonesia kecuali anggota diplomatik (Naopal et al., 2017).

\section{Temuan Audit}

Temuan dalam laporan audit bisa berisi tentang pelanggaran pada peraturan perundangan-undangan yang berlaku. Pelanggaran atau ketidakpatuhan tersebut kemungkinan akan berpengaruh terhadap penyusunan laporan keuangan. Adanya asimetri informasi mengenai keuangan daerah inilah yang dapat menyebabkan pemerintah daerah berlaku moral hazard, dan melakukan pelanggaran terhadap peraturan perundang-undangan terkait keuangan negara dan daerah untuk kepentingannya sendiri. Temuan BPK pada pemerintah daerah yang signifikan berarti bahwa pemerintah daerah tersebut memiliki perilaku penyimpangan yang kuat (moral hazard) dalam tata kelola pemerintahan. Temuan BPK seharusnya dapat digunakan oleh pemerintah daerah sebagai sarana untuk mengurangi penyimpangan (moral hazard) sehingga akuntabilitas laporan 
keuangan dapat diandalkan (Qowi dan Prabowo, 2017). Temuan audit dapat menggambarkan baik buruknya suatu kinerja dari instansi pemerintah daerah (Masdiantini dan Erawati, 2016).

\section{Opini Audit}

UU No 15 tahun 2004 menjelaskan bahwa opini merupakan pernyataan auditor berkaitan dengan tingkat kewajaran kandungan informasi yang ada pada laporan keuangan. Opini merupakan pernyataan auditor mengenai kesesuaian laporan keuangan dengan SAP. Opini auditor juga memuat kecukupan pengungkapan, efektivitas pengendalian internal serta kepatuhan organisasi pada peraturan yang berlaku. Opini audit terdiri dari 4 (empat) jenis yaitu:

a. Opini wajar tanpa pengecualian (unqualified opinion).

b. Opini wajar dengan pengecualian (qualified opinion).

c. Opini tidak wajar (adversed opinion).

d. Pernyataan menolak memberikan opini (disclaimer of opinion).

Opini audit dapat digunakan untuk menggambarkan pengelolaan aset suatu instansi. Instansi dengan opini WTP mengartikan bahwa pengelolaan aset dilakukan dengan baik. Begitu juga sebaliknya jika instansi memperoleh opini disclaimer berarti instansi tidak bisa mengelola aset dengan baik (Simamora and Halim 2015).

\section{Pengembangan Hipotesis}

Acuan yang digunakan oleh pemerintah daerah dalam menyusun laporan keuangan adalah Standar Akuntansi Pemerintahan (SAP). Laporan keuangan yang disusun merupakan bagian dari transparansi dan bentuk akuntabilitas kepada masyarakat sehingga harus mengacu pada SAP. Ketidakpatuhan atau kepatuhan pemerintah pada SAP akan menunjukkan kondisi laporan keuangan yang telah disusun selama periode tertentu oleh pemerintah (Maranatal dan Ratmono, 2017).

Pada sebuah organisasi, pengelolaan aset merupakan salah satu permasalahan yang penting. Semakin besar organisasi maka aset yang dimiliki akan semakin banyak dengan masalah yang kompleks. Semakin banyak aset tentunya memerlukan tatakelola yang baik dan usaha pengungkapan lebih banyak terutama pada pemeliharaan dan tata kelola aset. Organisasi yang memiliki aset yang banyak akan cenderung memperoleh presure yang besar dari masyarakat terkait dengan transparansi dan tata kelola aset yang dimiliki. Oleh karena itu, transparansi dan tata kelola pada aset akan menjamin akuntabilitas laporan keuangan (Khasanah dan Rahardjo, 2014). Penelitian yang dilakukan Mulyani dan Wibowo (2017) menyatakan bahwa ukuran perusahaan berpengaruh negatif dan signifikan. Berbeda dengan penelitian yang dilakukan Piotrowski dan Van Ryzin (2007); Serrano et al. (2009); Qowi dan Prabowo (2017); Khasanah dan Rahardjo (2014) menyatakan terdapat pengaruh positif dan signifikan antara ukuran organisasi terhadap pengungkapan LKPD. Semakin besar aset yang dimiliki maka semakin luas pengungkapan yang dilakukan. Berdasarkan beberapa temuan riset sebelumnya maka diajukan hipotesis sebagai berikut:

\section{$\mathrm{H}_{1}$ : Ukuran pemerintah daerah berpengaruh positif terhadap pengungkapan laporan keuangan daerah.}

Organisasi atau pemerintah daerah yang memiliki umur administratif lebih lama akan lebih patuh dalam memberikan informasi laporan keuangan. Selain itu umur administratif yang lama cenderung menyajikan informasi yang lebih lengkap (Sari dan Rasuli, 2015). Diasumsikan bahwa semakin tua umur pemerintahan maka pengalaman dan keahlian akan meningkat, sehingga informasi akuntansi yang diungkapkan dalam laporan keuangan pemda lebih banyak (Joshi, 2006). Beberapa riset sebelumnya menemukan bukti bahwa bahwa umur pemerintah daerah berpengaruh positif terhadap pengungkapan LKPD. Semakin lama pemerintah daerah berdiri maka akan 
semakin ahli dan berpengalaman sehingga pengungkapan laporan keuangan akan semakin luas (Lesmana, 2010; Setyaningrum dan Syafitri, 2012). Berdasarkan temuan beberapa riset sebelumnya maka yang diajukan hipotesis:

$\begin{aligned} \mathrm{H}_{2}: & \text { Umur pemerintah } \\ & \text { berpengaruh positif } \begin{array}{r}\text { daerah } \\ \text { terhadap }\end{array} \\ & \text { pengungkapan laporan } \\ & \text { pemerintah daerah. }\end{aligned}$

Jumlah penduduk dapat digunakan sebagai alat ukur yang menunjukkan kompleksitas suatu daerah. Semakin besar jumlah penduduk maka permasalahan yang dihadapi akan semakin kompleks. Tingkat permasalahan yang semakin kompleks akan mengakibatkan kebutuhan pengungkapan informasi yang semakin tinggi (Hilmi dan Martani, 2012). Beberapa penelitian sebelumnya menjelaskan bahwa besarnya jumlah penduduk berpengaruh negatif terhadap tingkat pengungkapan LKPD (Naopal et al., 2017; Martani dan Zaelani, 2011; Martani dan Lestari, 2010). Sementara penelitian lain menyatakan bahwa jumlah penduduk berpengaruh positif terhadap pengungkapan LKPD. Semakin banyak jumlah penduduk di suatu daerah maka semakin banyak permasalahan yang dihadapi sehingga memerlukan pengungkapan yang lebih luas (Hendriyani dan Tahar, 2015; Maria del Carmen et al., 2014). Berdasarkan beberapa riset sebelumnya maka diajukan hipotesis:

\section{$\mathrm{H}_{3}$ : Jumlah penduduk berpengaruh positif terhadap pengungkapan laporan keuangan pemerintah daerah.}

Laporan kepatuhan yang diberikan oleh auditor merupakan bagian dari Laporan Hasil Pemeriksaan (LHP). Laporan kepatuhan menggambarkan ketaatan pelaksanaan anggaran dengan peraturan yang berlaku. Apabila terdapat temuan pada laporan kepatuhan berarti terjadi penyimpangan pada pelaksanaan anggaran yang dapat mempengaruhi akuntabilitas laporan keuangan (Qowi dan Prabowo, 2017). Hasil penelitian Maranatal dan Ratmono (2017); Martani dan Lestari
(2010) menyatakan temuan audit berpengaruh negatif terhadap pengungkapan LKPD, sedangkan riset lain menyatakan bahwa temuan audit berpengaruh positif dan signifikan terhadap pengungkapan LKPD. Temuan yang diungkapkan oleh BPK akan memberikan konsekuensi adanya koreksi dan peningkatan pengungkapan, sehingga semakin banyak temuan akan semakin luas pengungkapan (Sari et al., 2015; Mustikarini dan Fitriasari, 2012). Berdasarkan temuan riset sebelumnya maka hipotesis yang diajukan adalah:

$\mathrm{H}_{4}$ : Temuan audit berpengaruh positif terhadap pengungkapan laporan keuangan pemerintah daerah.

Opini BPK menjadi suatu ukuran untuk menilai tingkat akuntabilitas pemerintah. Apabila pemerintah daerah memperoleh opini Wajar Tanpa Pengecualian (WTP) maka laporan keuangan pemerintah tersebut telah diungkapkan kepada stakeholder sesuai dengan peraturan yang berlaku. Berkaitan dengan pengungkapan laporan keuangan pemerintah daerah/kota, opini audit tidak hanya mempengaruhi pengungkapan wajib LKPD namun juga mempengaruhi secara positif terhadap pengungkapan secara sukarela. Semakin baik opini yang dihasilkan maka semakin baik kualitas laporan yang dihasilkan dan tingkat pengungkapannya (Wulandari dan Sulardi, 2018; Naopal et al., 2017; Sari et al., 2015). Berdasarkan temuan riset sebelumnya maka hipotesis yang diajukan adalah:

$\mathrm{H}_{5}$ : Opini audit berpengaruh positif terhadap pengungkapan laporan keuangan pemerintah daerah

\section{Metode Penelitian}

Populasi dan Sampel

Penelitian ini menggunakan sampel yaitu kabupaten dan kota di Jawa Tengah. Unit analisis yang digunakan adalah laporan keuangan tahun anggaran 20152017 dan telah diperiksa oleh Badan Pemeriksa Keuangan. Jumlah sampel pemerintah daerah yang ada di Jawa 
Tengah adalah 35 Pemerintah Daerah yang terdiri dari 6 (enam) pemerintah kota, dan 29 pemerintah kabupaten.

Teknik pengambilan sampel dalam penelitian ini menggunakan sampel jenuh (saturation sampling) yaitu pengambilan sampel jika seluruh populasi digunakan sebagai sampel dan tidak ada perubahan karakteristik pada sampel (Sugiyono, 2017; Sekaran dan Bougie, 2016; Budiarto, 2019). Sampel yang digunakan pada penelitian ini adalah LKPD pada 35 pemerintah daerah kabupaten/kota yang terdapat di Provinsi Jawa Tengah. Data diperoleh langsung dari Badan Pemeriksa Keuangan (BPK) Perwakilan Jawa Tengah. Pemilihan populasi dikarenakan Jawa Tengah merupakan provinsi dengan pengungkapan LKPD tertinggi diantara 28 provinsi lainya (Hilmi dan Martani, 2012).
Data yang digunakan dalam penelitian ini yaitu laporan keuangan pemerintah daerah (LKPD). Laporan keuangan yang digunakan adalah tahun 2015-2017. Pengambilan tahun pengamatan selama 3 tahun ditujukan karena untuk memperoleh hasil yang lebih baik karena penelitian sebelumnya hanya menganalisis data kurang dari 3 tahun (Pradipta dan Azizah, 2016; Naopal et., 2017; Setyaningrum dan Syafitri 2012; Mustikarini dan Fitriasari, 2012). Menurut metode pengambilan sampel, jumlah sampel yang digunakan dalam penelitian ini adalah 102 sampel. Jumlah ini sudah sesuai dengan rule of thumb bahwa penelitian akan memperoleh hasil yang baik jika jumlah sampel antara 30 sampai dengan 100 (Sekaran dan Bougie, 2016).

\section{Pengukuran Variabel}

Tabel 1: Pengukuran variabel

\begin{tabular}{|l|l|l|}
\hline NO & \multicolumn{1}{|c|}{ Pengukuran Variabel } & \multicolumn{1}{|c|}{ Sumber } \\
\hline 1. & DISC $=\frac{\text { Total item yg diungkapkan }}{\text { total item yg harus diungkapkan }} \mathrm{x}$ 100 & Lesmana (2010) \\
\hline 2. & Size $=$ Ln Total asset & Hilmi dan Martani (2012) \\
\hline 3. & $\begin{array}{l}\text { Age }=2015-\quad \text { th penetapan UU } \\
\text { pembentukan pemda })\end{array}$ & Suranta dan Siregar (2015) \\
\hline 4. & Pop = Ln Jumlah Penduduk & Naopal et al. (2017) \\
\hline 5. & Finds = Jumlah Temuan & Sendriyani dan Tahar (2015) \\
\hline 6. & $\begin{array}{l}\text { Opinion al. (2015) } \\
4=\text { Wajar Tanpa Pengecualian } \\
3=\text { Wajar Dengan Pengecualian } \\
2=\text { Tidak Wajar } \\
1=\text { Tidak Berpendapat }\end{array}$ & \\
\hline
\end{tabular}


Table 2: Sampel Penelitian

\begin{tabular}{|l|l|l|l|}
\hline & Deskripsi & Jumlah & Hasil \\
\hline Kabupaten & Jumlah LKPD kabupaten & $29 \times 3$ th & 87 \\
\hline Kota & Jumlah LKPD Kota & $6 \times 3$ th & 18 \\
\hline & LKPD yang tidak dapat digunakan & & $(3)$ \\
\hline Jumlah & & & 102 \\
\hline
\end{tabular}

Tabel 3: Hasil Statistik Deskripsi

\begin{tabular}{|lcccr|}
\hline \multicolumn{5}{c|}{ Descriptive Statistics } \\
\hline Variabel & Min & Max & Mean & Std. Dev \\
\hline Disc. & 30,30 & 69,70 & 52,58 & 9,62 \\
Size & 20,04 & 31,00 & 28.53 & 1,54 \\
Age & 33,00 & 65,00 & 63,81 & 6,43 \\
Pop & 12,10 & 14,00 & 13,71 & 0,62 \\
Finds & 3,00 & 4,00 & 7,03 & 3,86 \\
Opini & 3,00 & 4,00 & 3,76 & \\
\hline
\end{tabular}

Sumber: Data sekunder diolah tahun 2017

Table 4: Hasil Uji Hipotesis

\begin{tabular}{|l|l|l|l|l|}
\hline \multicolumn{1}{|c|}{ Variabel } & \multicolumn{1}{|c|}{$\beta$} & \multicolumn{1}{c|}{$\mathrm{t}$} & \multicolumn{1}{c|}{ Sig. } & \multicolumn{1}{c|}{ Keterangan } \\
\hline Size & 0,036 & 0,368 & 0,714 & $\mathrm{H}_{1}$ : tidak terbukti \\
Age & $-0,212$ & $-1,983$ & $0,050^{*}$ & $\mathrm{H}_{2}$ : tidak terbukti \\
Pop & 0,389 & 3,613 & $0,000^{* *}$ & $\mathrm{H}_{3}$ : terbukti \\
Finds & 0,001 & 0,003 & 0,998 & $\mathrm{H}_{4}:$ tidak terbukti \\
Opini & $-0,114$ & $-1,160$ & 0,249 & $\mathrm{H}_{5}:$ tidak terbukti \\
\hline F hitung: & 2,809 & $0,021^{* *}$ \\
\hline Adj R ${ }^{2}:$ & 0,084
\end{tabular}

Sumber: Data sekunder diolah tahun 2017; * sig < 10\%, ** sig < 5\%

Teknik Analisis Data

Analisis Regresi Berganda

Analisis regresi berganda digunakan untuk menguji pengaruh variabel independen terhadap variabel dependen. Analisis regresi berganda pada penelitian ini adalah: $Y=\alpha+\beta_{1} X_{1}+\beta_{2} X_{2}+\beta_{3} X_{3}+\beta_{4} X_{4}+\beta_{5} X_{5}$ $+\mathrm{e}$ 
Keterangan:

$\begin{array}{ll}\mathrm{Y}_{1} & \text { : Luas pengungkapan } \\ \mathrm{X}_{1} & \text { : Ukuran pemda } \\ \mathrm{X}_{2} & \text { : Umur pemda } \\ \mathrm{X}_{3} & \text { : Jumlah penduduk } \\ \mathrm{X}_{4} & \text { : Temuan Audit } \\ \mathrm{X}_{5} & \text { : Opini Audit } \\ \mathrm{a} & \text { : Konstanta } \\ \beta & \text { : Koefisien regresi } \\ \mathrm{e} & \text { : Eror term }\end{array}$

\section{Hasil Penelitian}

\section{Data Penelitian}

Jumlah sampel sebanyak 102 laporan keuangan pemerintah daerah yang terdapat pada kawasan Jawa Tengah yang ditunjukkan pada tabel 2. Hasil dari uji statistik deskriptif (Tabel 3) menunjukkan rata-rata (mean) adalah sebesar 52,58; nilai minimum sebesar 30,30 dan maksimum sebesar 69,70 pada variabel pengungkapan. Nilai rata-rata (mean) sebesar 28,53 pada variabel ukuran Pemda (size), 63,81 pada umur Pemerintah Daerah (age), 13,71 pada variabel jumlah penduduk (pop), dan 7,03 pada variabel temuan audit (finds). Nilai mean pada 4 variabel diatas lebih besar dari standar deviasi hal ini berarti bahwa data yang dianalisis memiliki representasi yang baik. Nilai minimum opini audit (opini) menunjukkan peringkat yaitu 1 untuk opini tidak berpendapat sampai 4 untuk opini WTP.

\section{Uji Hipotesis dan Pembahasan}

Uji hipotesis dalam riset ini menggunakan alat analisis regresi berganda dengan signifikansi $5 \%$. Hasil pengujian hipotesis ditunjukkan pada tabel 4 . Berdasarkan analisis pada tabel 4 dapat disusun persamaan regresi linear berganda pada penelitian ini adalah sebagai berikut:

Tingkat Pengungkapan LKPD $=0,036$ Size - 0,212age + 0,389Pop + 0,001Finds 0,114Opini + e

Pengaruh Ukuran Pemerintah Daerah terhadap Tingkat Pengungkapan LKPD
Hasil analisis menunjukkan bahwa ukuran Pemda (size) memiliki koefisien beta sebesar 0,036 dan $\mathrm{p}$ value sebesar 0,714 (tidak signifikan). Hal ini menunjukkan bahwa variabel independen yaitu ukuran Pemda (size) tidak berpengaruh pada tingkat pengungkapan LKPD. Hasil penelitian ini menunjukkan bahwa ukuran pemerintah yang besar tidak menjamin tingginya pengungkapan. Permasalahan yang sering dihadapi pemerintah daerah di lapangan adalah kesulitan melakukan pencatatan aset karena jumlahnya yang sangat banyak. Semakin banyak aset yang dimiliki maka akan semakin kompleks permasalahan yang dihadapi sehingga pengungkapan informasi menjadi kendala dalam penyusunan laporan keuangan. Hasil penelitian ini didukung oleh temuan Naopal et al. (2017) yang menjelaskan bahwa pemerintah daerah memiliki aset tetap yang jumlahnya lebih besar dibandingkan aset lancar dan persediaan. Aset tetap yang besar ini sering menimbulkan permasalahan karena kesulitan dalam pencatatan sehingga nilai aset yang dilaporkan tidak sesuai. Permasalahan pencatatan aset ini sering menjadi temuan auditor pemeriksa apalagi tidak didukung oleh bukti pencatatan yang valid. Hasil riset ini didukung oleh penelitian Setyaningrum dan Syafitri (2012) yang menyatakan bahwa ukuran pemerintah daerah yang diukur dengan total aset tidak memiliki pengaruh yang signifikan terhadap tingkat pengungkapan LKPD.

\section{Pengaruh Umur Pemerintah Daerah terhadap Tingkat Pengungkapan LKPD. \\ Hasil analisis menunjukkan bahwa} koefisien beta pada variabel umur Pemda (age) adalah -0,212 dengan $\mathrm{p}$ value sebesar 0,050 (signifikan < 10\%). Hal ini menunjukkan bahwa variabel umur Pemda (age) berpengaruh negatif signifikan terhadap tingkat pengungkapan LKPD. Hasil riset ini membuktikan bahwa semakin tua umur administratif pemerintah maka tingkat pengungkapan LKPD yang disajikan akan semakin sedikit. Hasil analisis yang menunjukkan hubungan negatif antara umur pemda dengan tingkat 
pengungkapan LKPD membuktikan bahwa pemerintah daerah yang memiliki umur administratif yang sudah lama akan mempunyai keahlian dan pengalaman dalam menyajikan laporan keuangan sehingga sesuai dengan SAP. Seiring dengan berjalannya waktu, pemerintah daerah akan belajar dari kesalahan sehingga dapat memperbaiki kekurangan yang terjadi pada laporan keuangan periode sebelumnya. Pemerintah daerah yang memiliki umur administratif yang lebih lama tentunya memiliki pengalaman dalam hal pemeriksaan auditor sehingga dapat mengantisipasi adanya temuan audit. Dengan pengalaman yang dimiliki baik penyusunan laporan maupun pemeriksaan auditor, pemerintah daerah akan dapat mengeliminasi salah saji yang terdapat pada laporan keuangan (Setyaningrum dan Syafitri, 2012; Naopal et al., 2017).

\section{Pengaruh Jumlah Penduduk terhadap Tingkat Pengungkapan LKPD.}

Hasil riset membuktikan bahwa koefisien beta pada variabel jumlah penduduk (рор) adalah sebesar 0,389 dengan $\mathrm{p}$ value sebesar 0,000 (signifikan). Hasil penelitian ini membuktikan bahwa variabel jumlah penduduk ( berpengaruh signifikan terhadap tingkat pengungkapan LKPD pemerintah daerah di Jateng. Jumlah penduduk suatu daerah kabupaten/kota berbanding signifikan dengan tingkat pengungkapan informasi pada laporan keuangan. Menurut UU no 33 tahun 2004 pasal 28 jumlah penduduk berbanding lurus dengan kebutuhan pelayanan kepada masyarakat. Jumlah penduduk yang besar akan membutuhkan berbagai macam fasilitas untuk memenuhi kepuasan publik. Sebagai fungsi pelayanan kepada masyarakat, maka pemerintah daerah akan berusaha mengungkapkan seluruh informasi pada laporan keuangan. Hasil penelitian ini sejalan dengan riset sebelumnya yang mengungkapkan hubungan positif antara jumlah penduduk dengan luas pengungkapan (Hendriyani dan Tahar, 2015).

\section{Pengaruh Temuan Audit terhadap Tingkat Pengungkapan LKPD.}

Hasil analisis menunjukkan bahwa koefisien beta pada variabel temuan audit (finds) adalah sebesar 0,001 dengan $\mathrm{p}$ value 0,998 (tidak signifikan). Hal ini menunjukkan bahwa variabel temuan audit (finds) tidak berpengaruh signifikan terhadap tingkat pengungkapan LKPD. Tingginya temuan audit di beberapa pemerintah kabupaten tidak diikuti dengan signifikansi pengungkapan informasi pada laporan keuangan yang disajikan. Hasil penelitian ini mendukung beberapa riset sebelumnya tentang pengungkapan laporan keuangan di pemerintah daerah. Hasil riset ini dapat dijelaskan bahwa variabel temuan audit kemungkinan kurang tepat untuk mengukur kualitas temuan. Variabel temuan audit pada penelitian ini hanya didasarkan pada jumlah kuantitatif temuan atau banyaknya temuan tanpa memperhitungkan materialitas temuan. Jumlah temuan yang dihitung kemungkinan banyak tetapi jumlahnya tidak material atau kemungkinan jumlah temuan sedikit tetapi material terhadap laporan keuangan. Jumlah temuan yang membutuhkan tindak lanjut karena materialitas pada laporan keuangan jumlahnya bisa jadi hanya sedikit. (Waliyyani dan Mahmud, 2015; Hendriyani dan Tahar, 2015; Naopal et al., 2017).

\section{Pengaruh Opini Audit terhadap terhadap Tingkat Pengungkapan LKPD.}

Hasil riset menunjukkan bahwa koefisien beta pada variabel opini audit (opini) adalah sebesar -0,114 dengan $\mathrm{p}$ value 0,249 (tidak signifikan). Hasil penelitian ini membuktikan bahwa opini audit (opini) tidak memiliki pengaruh signifikan terhadap tingkat pengungkapan LKPD. Opini audit merupakan representasi dari kualitas laporan keuangan yang disajikan pemerintah daerah karena memuat informasi tetang tata kelola sumberdaya yang telah digunakan. Pemerintah daerah yang memiliki opini audit WTP berarti memiliki standar pelaporan yang dapat diandalkan dan tentunya sesuai dengan standar yang sudah ditentukan yaitu standar akuntansi pemerintah. Hasil riset ini 
membuktikan bahwa Opini WTP yang diperoleh pemerintah daerah tidak mencerminkan luas pengungkapan, namun hanya untuk menemukan kecurangan yang mungkin dilakukan oleh pemerintah daerah (Naopal et al., 2017; Indrarti 2011).

\section{Kesimpulan}

Berdasarkan hasil penelitian dapat ditarik dua kesimpulan yaitu: pertama umur administratif pemerintah daerah dan jumlah penduduk memiliki pengaruh signifikan terhadap tingkat pengungkapan. Kedua, ukuran pemerintah daerah, opini audit dan temuan audit tidak memiliki pengaruh signifikan terhadap tingkat pengungkapan. Hasil penelitian ini juga menunjukkan bahwa rata-rata tingkat pengungkapan Laporan Keuangan Pemerintah Daerah (LKPD) Kabupaten/Kota di Jawa Tengah tahun 2015-2017 sebesar 52\% meningkat dari temuan sebelumnya yaitu penelitian Lesmana (2010) sebesar $22 \%$.

\section{Keterbatasan dan Saran}

Keterbatasan pada penelitian ini adalah pertama, penelitian ini hanya menggunakan data laporan keuangan pemerintah daerah di Jawa Tengah selama 3 tahun yakni 20152017. Untuk penelitian yang akan datang dapat memperluas sampel penelitian dan jumlah tahun yang lebih banyak, karena banyaknya sampel akan mempengaruhi hasil penelitian (Alharbi and Drew, 2014). Keterbatasan kedua adalah bahwa penelitian ini hanya meneliti variabel karakteristik daerah, opini, temuan audit dan jumlah penduduk. Saran untuk penelitian selanjutnya dapat menambahkan jumlah SKPD karena banyaknya SKPD menunjukkan adanya diferensiasi fungsional pada pemda yang kemungkinan dapat meningkatkan jumlah informasi dan luas pengungkapan (Mandasari, 2009).

\section{Daftar Pustaka}

Alhajjriana, G. I., W, Nor., \& R, Wijaya. (2017). Faktor-faktor yang mempengaruhi internet financial reporting pemerintah daerah dan implikasinya terhadap akuntabilitas laporan keuangan daerah. Jurnal Akuntansi dan Bisnis, 17(2): 100109.

Alharbi, S., \& S, Drew. (2014). Using the technology acceptance model in understanding academics behavioral intention to use learning management systems. International Journal of Advanced Computer Science and Applications, 5(1): 143-155.

Aziz, A. (2016). Pengaruh karakteristik pemerintah daerah terhadap kinerja keuangan pemerintah daerah (Studi pada Pemerintah Daerah Kabupaten/Kota di Jawa Timur). Eksis: Jurnal Riset Ekonomi dan Bisnis, 11(1).

Budiarto, D. S. (2019). Panduan Riset Kuantitatif: Trik Publikasi bagi Pemula. Edisi 1, Penerbit UPYPress, Yogyakarta.

Bowrey, G. (2007). Have recent financial reforms improved financial accountability in the Australian Commonwealth public sector? Australasian Accounting, Business and Finance Journal, 1(3): 4-15.

Dewi, I. A. P. O. Y., \& G. W, Yasa. (2017). Pengaruh ukuran perusahaan, profitabilitas, tipe industri dan kinerja lingkungan terhadap environmental disclosure. E-Jurnal Akuntansi: 2362-2391

Hendriyani, R., \& A, Tahar. (2015). Analisis faktor-faktor yang memengaruhi tingkat pengungkapan laporan keuangan pemerintah provinsi di Indonesia. Jurnal Bisnis dan Ekonomi, 22(1): 29-31.

Hilmi, A. Z., \& D, Martani. (2012). Analisis faktor-faktor yang mempengaruhi tingkat pengungkapan laporan keuangan pemerintah provinsi. Simposium Nasional Akuntansi, 15: 13-20.

Indrarti, N. M. (2011). Hubungan antara opini Audit pada Laporan Keuangan Daerah, Pendapatan Asli Daerah dan Dana Alokasi Umum terhadap kinerja keuangan daerah. Naskah Publikasi Universitas Riau. 
https://repository.unri.ac.id

Jaya, J. D., \& E. A, Sisdyani. (2014). Pengaruh pendapatan asli daerah, dana alokasi umum, dan belanja modal pada kelengkapan pengungkapan informasi keuangan daerah melalui situs resmi pemerintah provinsi. E-Jurnal Akuntansi: 162-179.

Joshi, D. (2006). Disclosure practices in corporate reporting of public sector financial institutions (Psfs). 1-16.

Khasanah, N. L., \& S. N, Rahardjo. (2014). Pengaruh karakteristik, kompleksitas, dan temuan audit terhadap tingkat pengungkapan laporan keuangan pemerintah daerah. Diponegoro Journal Of Accounting, 3(2): 864874.

Lesmana, S. I. (2010). Pengaruh karakteristik pemerintah daerah terhadap tingkat pengungkapan wajib di Indonesia. Universitas Sebelas Maret Surakarta. Tesis. 5-46.

Mandasari, P. (2009). Practices of mandatory disclosure compliance in Indonesian local government. Tesis Master, Universitas Sebelas Maret.

Maranatal, L., \& D, Ratmono. (2017). Analisis faktor-faktor yang mempengaruhi kepatuhan terhadap SAP oleh pemerintah daerah. Diponegoro Journal Of Accounting, 6(1): 244-255.

Marfiana, N., \& L, Kurniasih. (2013). Pengaruh karakteristik pemerintah daerah dan hasil pemeriksaan audit BPK terhadap kinerja keuangan pemerintah daerah kabupaten/kota. Sustainable Competitive Advantage (SCA) 3(1): 3-12.

María del Carmen, C. A. B. A., Boliviar, M. P. R., \& Hernandez, A. M. L. (2014). The determinants of government financial reports online. Transylvanian Review of Administrative Sciences, 10(42): 531.

Martani, D., \& A, Lestari. (2010). Local government financial statement disclosure in Indonesia. Conference
Proceedings: Asian Academic Accounting Association, 1-23.

Martani, D., \& F, Zaelani. (2011). Pengaruh ukuran, pertumbuhan, dan kompleksitas terhadap pengendalian intern pemerintah daerah studi kasus di Indonesia. Simposium Nasional Akuntansi XIV. Aceh. 1-26.

Masdiantini, P. R., \& N. M. A, Erawati. (2016). Pengaruh ukuran pemerintah daerah, kemakmuran, intergovernmental revenue, temuan dan opini audit BPK pada kinerja keuangan. E-Jurnal Akuntansi: 11501182.

Mulyani, S., \& H, Wibowo. (2017). Pengaruh belanja modal, ukuran pemerintah daerah, intergovernmental revenue dan pendapatan asli daerah terhadap kinerja keuangan (Kabupaten/Kota di Provinsi Jawa Tengah, tahun 20122015). Kompartemen: Jurnal Ilmiah Akuntansi, 15(1): 1-10.

Mustikarini, W. A., \& D, Fitriasari. (2012). Pengaruh karakteristik pemerintah daerah dan temuan audit BPK terhadap kinerja pemerintah daerah kabupaten/kota di Indonesia tahun anggaran 2007. Forum: Simposium Nasional Akuntansi, (XV): 12-15.

Naopal, F., Rahayu, S., \& Yudowati, S. P. (2017). Pengaruh karaktersitik daerah, jumlah penduduk, temuan audit, dan opini audit terhadap pengungkapan laporan keuangan pemerintah daerah. Assets, 7(1): 5668.

Niu, F. A. L., Karamoy, H., \& Tangkuman, S. (2014). Analisis penerapan PP. No. 71 Tahun 2010 dalam penyajian laporan keuangan dinas pendapatan pengelolaan keuangan dan aset daerah kota Kotamobagu. Jurnal Emba: Jurnal Riset Ekonomi, Manajemen, Bisnis dan Akuntansi, 2(4): 714-722.

Nurkhin, A. (2009). Corporate governance dan profitabilitas; Pengaruhnya terhadap pengungkapan tanggung jawab sosial perusahaan (studi empiris pada perusahaan yang 
tercatat di Bursa Efek Indonesia). Tesis, Program Pascasarjana Universitas Diponegoro. 1-97

Nurtari, Fadilah., \& Nucholisah. (2016). Pengaruh karakteristik dan kompleksitas pemerintah daerah terhadap pengungkapan laporan keuangan (Studi Pada LKPD Kota/Kabupaten di Provinsi Jawa Barat Periode 2013-2014). Jurnal Fakultas Ilmu Ekonomi dan Bisnis Universitas Islam Bandung, 2(1): 263-270

Piotrowski, S. J., \& G. G. Van Ryzin. (2007). Citizen attitudes toward transparency in local government. The American Review of Public Administration, 37(3): 306-323.

Pradipta, F., \& D, Azizah. (2016). Pengaruh ukuran perusahaan, leverage, profitabilitas, dan likuiditas terhadap luas pengungkapan wajib laporan keuangan (Studi empiris pada perusahaan manufaktur yang terdaftar di Bursa Efek Indonesia tahun 2013-2014). Jurnal Administrasi Bisnis, 36(1): 101-110.

Pradono, F. C. (2015). Kualitas laporan keuangan pemerintah daerah: faktor yang mempengaruhi dan implikasi kebijakan (Studi pada SKPD pemerintah provinsi Jawa Tengah). Jurnal Bisnis dan Ekonomi, 22(2):188-200.

Qowi, R., \& T. J. W, Prabowo (2017). Pengaruh karakteristik pemerintah daerah dan temuan pemeriksaan BPK terhadap kinerja pemerintah daerah kabupaten/kota di Indonesia tahun anggaran 2012. Diponegoro Journal of Accounting, 6(1): 298-310.

Sari, A. P., Martani, D., \& D, Setyaningrum. (2015). Pengaruh temuan audit, tindak lanjut hasil pemeriksaan dan kualitas sumber daya manusia terhadap opini audit melalui tingkat pengungkapan laporan keuangan kementerian/lembaga. Simposium Nasional Akuntansi XVIII. Medan.

Sari, R. N., \& M. Rasuli. (2015). Pengaruh sistem pengendalian intern, kepatuhan terhadap peraturan perundang-undangan, opini audit tahun sebelumnya dan umur pemerintah daerah terhadap penerimaan opini wajar tanpa pengecualian pada laporan keuangan pemerintah daerah di seluruh Indonesia. Jurnal Akuntansi (Media Riset Akuntansi \& Keuangan), 3(1): 1-15.

Sekaran, U., \& R. J, Bougie. (2016). Research method for business: A Skill-building approach: 7th edition, Wiley \& Son

Serrano-Cinca, C., Rueda-Tomas, M., \& P, Portillo-Tarragona. (2009). Factors influencing e-disclosure in local public administrations. Environment and Planning C: Government and Policy, 27(2): 355-378.

Setyaningrum, D., \& F, Syafitri. (2012). Analisis pengaruh karakteristik pemerintah daerah terhadap tingkat pengungkapan laporan keuangan. Jurnal Akuntansi dan Keuangan Indonesia, 9(2): 154-170.

Simamora, R., \& A, Halim. (2013). Faktorfaktor yang mempengaruhi pengelolaan aset pasca pemekaran wilayah dan pengaruhnya terhadap kualitas laporan keuangan Pemerintah di Kab. Tapanuli Selatan. Jurnal Ekonomi dan Bisnis, 13(2): 29-43.

Suhardjanto, D., \& R. R, Yulianingtyas. (2011). Pengaruh karakteristik pemerintah daerah terhadap kepatuhan pengungkapan wajib dalam laporan keuangan pemerintah daerah (Studi empiris pada Kabupaten/Kota di Indonesia). Jurnal Akuntansi dan Auditing, 8(1): $30-42$.

Sugiyono. (2017). Metode penelitian kebijakan: pendekatan kuantitatif, kualitatif, kombinasi, $R \& D$ dan penelitian evaluasi. Penerbit Alfabeta, Bandung.

Sulisnaningrum, E., \& B. H, Prabowo. (2017). Pengaruh faktor-faktor keuangan terhadap kelengkapan pengungkapan laporan keuangan 
berbasis SAK Etap pada koperasi wanita kota Malang. Koordinasi Perguruan Tinggi Swasta (KOPERTIS) Wilayah VII, 10(2): 5358.

Suranta, S., \& O, Siregar. (2015). Pengaruh karakteristik pemerintah daerah terhadap kepatuhan pengungkapan investasi pemerintah daerah (Studi pada pemerintah Kabupaten/Kota di Pulau Jawa dan Sumatera). Jurnal Akuntansi, 3(1): 79-93.

Undang-Undang Republik Indonesia Nomor 15 Tahun 2004 Tentang Pemeriksaan Pengelolaan Dan Tanggung Jawab Keuangan Negara Pasal 1

Undang-Undang Republik Indonesia Nomor 15 Tahun 2004 Tentang Pemeriksaan Pengelolaan Dan Tanggung Jawab Keuangan Negara Pasal 16 Ayat 1

Undang-Undang Republik Indonesia Nomor 71 Tahun 2010 Lampiran I.01 Pernyataan 01 Tentang Penyajian Laporan Keuangan Tentang Standar Akuntansi Pemerintahan

Walliyani., \& Mahmud. (2015). Pengaruh karakteristik pemerintah terhadap tingkat pengungkapan laporan keuangan pemerintah daerah di Indonesia. E-Jurnal Akuntansi, Universitas Negeri Semarang: 1-8.

Wahyuningsih, W., R, Arifati., \& K, Raharjo. (2016). Pengaruh likuiditas, leverage, profitabilitas, porsi saham publik, ukuran perusahaan dan umur perusahaan terhadap kelengkapan pengungkapan laporan keuangan pada perusahaan manufaktur yang terdaftar di Bursa Efek Indonesia dengan periode penelitian tahun 2 . Journal Of Accounting, 2(2): 1-12.

Wulandari, N. A., \& S, Sulardi. (2018). Pengaruh karakteristik daerah, temuan, dan opini audit terhadap pengungkapan sukarela (Studi Empiris pada Website Pemda di Indonesia). Akuntansi Dewantara, 2(1): 69-82.

Yusuf, M. (2010). Delapan langkah pengelolaan aset daerah menuju pengelolaan keuangan daerah terbaik. Salemba Empat, Yogyakarta www.bappeda.jatengprov.go.id

www.jateng.bps.go.id www.semarang.bpk.go.id 

Jurnal Akuntansi Bisnis 